\title{
Determining Misbehaviors Encountered by Physical Education Teachers and Their Opinions about the Methods Used Against to Those Behaviors
}

\author{
Anıl Onur Mercanoğlu (Corresponding author) \\ Department of Recreation and Sports, Faculty of Sport Sciences \\ Eskişehir Technical University, Eskişehir, 26000, Turkey \\ Tel: 90-546-458-6523Ｅ-mail: aomercanoglu@eskisehir.edu.tr
}

Received: August 11, $2021 \quad$ Accepted: September 15, 2021

Published: October 9, 2021

doi:10.5296/jei.v7i2.18961ＵRL: https://doi.org/10.5296/jei.v7i2.18961

\begin{abstract}
Determining the misbehaviors encountered in physical education classes and the methods used against these behaviors is important both in terms of producing new solutions by revealing the current situation in classroom management and providing a preliminary information for teachers who will just start the profession. The aim of the study is to determine the physical education teachers' views who work at schools in Yenimahalle district in Ankara about student misbehaviors and their opinions about the methods used against to those behaviors in physical education lessons. The research group consists of 100 physical education teachers in total who were chosen with convenience sampling method and work at public schools in Yenimahalle district. The questionnaire used to collect data consists of two parts. In the first part, there are items related to student misbehaviors. In the second part, there are items related to the methods used against student misbehaviors. The four-point Likert rating system was applied and the items were rated as "never", "seldom", "usually", "always". According to the findings, it revealed that the misbehavior most frequently encountered by physical education teachers is "complaining about friends to the teacher" and the misbehavior that they usually meet is "talking in class without asking permission". It was determined that the methods most frequently used by the physical education teachers in the research group were "rewarding positive behaviors" and "attracting students' attention to the lesson by asking questions about the subject of the lesson". It can be stated that these results will serve as a guide especially in the preparation process of physical education teacher candidates.
\end{abstract}


Keywords: Student misbehavior, Undesirable student behavior, Physical education lesson, Classroom management

\section{Introduction}

Controlling student behavior is considered to be the most important component of classroom management. For this reason, it is seen that the literature focuses on this subject (Cothran \& Kulinna, 2007). The most important factor that hinders and interrupts teaching and causes the teaching time to be allocated to non-teaching activities is student misbehaviors. For this reason, the main purpose of classroom management is to prevent the emergence of student misbehaviors in the classroom and to stop and change the emerging behaviors in a positive way (Erden, 2001). Since students tend to defend themselves by comparing their misbehaviors in physical education classes with other more severe deviant behaviors, it may be necessary to inform them about this behaviors (Hsu \& Pan, 2018). There are many different criteria for a behavior to be called a problem behavior. Criteria such as whether the behavior of the individual harms others or causes discomfort to other friends, whether it prevents his/her friends from learning, whether it harms the teacher can be listed as priority. Different researchers have made different rankings on this subject. The most important reason why these rankings are different is the variety of student misbehaviors. There are so many problem behaviors in or out of the classroom that it is sometimes not possible to list them all. It will be easier to categorize and examine these behaviors and to research them (Danaoğlu, 2009).

In general, student misbehaviors are described as behaviors that hinder the teaching process. These behaviors include symptoms such as attention deficit, disobedience, and lack of participation (Kohútová et al., 2021). Studies also show that student misbehaviors hinder the teaching process (Daddis \& Meadows, 2021; Thilagaratnam \& Yamat, 2021). Misbehavior can change according to class, lesson, time and situation. So it is quite difficult to list and define the misbehavior that everyone agrees on. However, there are four basic criteria in order to call the behaviors of students in the classroom as misbehavior (Kaya, 2002):

(1) The behavior prevents the student or classmates from learning.

(2) The behavior puts the student at risk for himself/herself or his/her friends.

(3) The behavior damages the school equipment or the belongings of friends.

(4) Behavior prevents the student from socializing with other students.

Some of the misbehaviors are not seen as disruptive behavior, but as directive behavior. Not bringing course materials such as books and notebooks, forgetting his sweatpants and sneakers, being unable to complete his homework, and staying away from classroom activities are among these (Lemlech, 1988). The teacher should not consider these as unimportant and ignore them. These prevent the achievement of goals in terms of the development of the student, as well as facilitate other undesirable disruptive behaviors after a step or two, and become the cause of them. It is seen that the increase in such behaviors negatively affects the teacher-student relationship, and as a result, it causes an increase in 
teacher's emotional exhaustion and a decrease in work enthusiasm (Aldrup et al., 2018).

Good classroom management for physical education lessons is more vital than academic lessons. This may be due to the fact that a wide variety of movements are provided, the opportunity to move freely in a different environment from the classroom environment, with different tools, and the lessons are held in a more crowded classroom environment compared to academic lessons (Harrison \& Blakemore, 1992).

There are some strategies for controlling misbehaviors. These are stated as evoking the desired behavior, making people believe in the desired behavior, strengthening the desired behavior, facilitating the desired behavior (Başar, 1999). The first condition of being able to show the desired behavior continuously is to have the knowledge of that behavior. This ownership starts in the family. The family should teach the behaviors related to cleanliness, order, the rights and responsibilities of being in a place, these should be reinforced at school, and the missing ones should be completed. Washing hands, cleaning the soap after use, brushing your teeth, closing the door, pushing it back when getting up from the chair, walking on the right side of the road, listening to others talking, not making noise when wiping your nose, not opening your mouth while chewing, not speaking when there is food in your mouth, using time appropriately, are examples of such behaviors. can be given. Another condition for observing the desired behavior is the appropriate environment. By making the environment suitable, any desired behavior can be made. If you want the student to wash their hands, put soap in the sinks, if you want them not to be bothering each other, stay in them until they are accustomed to appropriate behavior, so they know you have an eye on them. If you don't want him/her to wipe his/her nose with his/her hand, give him/her a handkerchief, if you don't want them to come in with muddy shoes, put grills and mats on the entrance doors etc. (Başar, 2010).

With this research, it is expected that the most common misbehaviors and the solution strategies for these behaviors are determined and it is expected to contribute to the educators about what precautions should be taken against student misbehaviors. Because, with the use of the longest-lasting and effective solution methods in the face of misbehaviors, teachers will be able to provide a higher quality education by eliminating misbehaviors in education and minimizing time loss in education. Increasing the quality of education will allow the training of more qualified individuals. Thus, an environment with healthier relationships in the classroom will be provided. At the same time, with this research, more realistic evaluations can be made with the coping strategies applied by physical education teachers. Thus, it will be discussed by considering the solution methods for the misbehavior used by the teachers and will enable new researches.

Misbehaviors negatively affect the effective use of time in the lesson and the quality of the lesson. This situation affects both the student exhibiting the misbehavior and the other students in the class. Since the environment (gym, field, garden, etc.) where the physical education lesson is taught and the teaching methods used in the lesson are different from other lessons, there will be differences in misbehaviors. This research aims to determine the student misbehaviors that physical education teachers working in schools in a central district 
of Ankara encountered and the methods that teachers use against these behaviors.

Two sub-problems arise in line with the purpose of the research;

(1) What are the student misbehaviors that physical education teachers encounter in physical education classes?

(2) What are the opinions of physical education teachers on the solution of student misbehaviors?

\section{Method}

\subsection{The Study Group}

The research group consists of 100 physical education teachers working in public schools in a central district of Ankara. Participants who was chosen with convenience sampling method work at schools in Yenimahalle district. Participants were informed in writing that they could withdraw from the study at any time during the data collection process.

\subsection{Data Collection Tools}

The questionnaire determining the views about student misbehaviors and teachers' opinions about the methods used against to those behaviors in lesson was developed by Sayı (2001). The questionnaire used to collect data consists of two parts. In the first part, there are 28 items related to student misbehaviors. In the second part, there are 23 items related to the methods used against student misbehaviors. In the original questionnaire, there were 31 items in the first part and 24 items in the second part, but 4 items that were not related to the physical education lesson were removed. Four point likert rating system was applied and the items were rated as "never", "seldom", "usually", "always".

\subsection{Data Analysis}

The collected questionnaires were evaluated and incomplete and incorrectly filled ones were excluded from the evaluation. The data in the questionnaires were analyzed through the statistical package program. Percentage and frequency analyzes were used to analyze the data belonging to the sub-problems.

\section{Results}

\subsection{Results of the First Sub-Problem}

When the data belonging to the first sub-problem examined in order to determine the misbehaviors encountered in physical education classes, it has been determined that "complaining about friends to the teacher" is always seen at the rate of $37 \%$, "avoiding classroom tasks given by the teacher" is usually seen at the rate of $47 \%$, "arriving late to class" is usually seen at the rate of $62 \%$, "making unnecessary noise" is usually seen at the rate of $68 \%$, and "talking in class without asking permission" is usually seen at the rate of $72 \%$ (Table 1).

The misbehaviors that teachers seldom encounter are "being disrespectful to the teacher" at 
the rate of $60 \%$, "absence from school without a valid reason" at the rate of $64 \%$, "wandering aimlessly around the classroom" at the rate of $64 \%$, "damaging their friends' belongings" at the rate of $76 \%$, and "hitting or pushing" at the rate of $65 \%$ (Table 1 ).

The misbehaviors that teachers never encounter include "complaining about friends to the teacher" at the rate of $20 \%$, "singing or whistling in the lesson" at the rate of $36 \%$, "eating and drinking during the lesson" at the rate of $19 \%$, "bringing their belongings to the lesson" at the rate of $20 \%$ (Table 1$)$.

Table 1. Percentages of misbehaviors encountered in physical education lessons

\begin{tabular}{|c|c|c|c|c|}
\hline Misbehaviors $(\mathrm{n}=100)$ & Never $(\%)$ & Seldom $(\%)$ & Usually (\%) & Always (\%) \\
\hline Being disrespectful to the teacher & 7 & 33 & 60 & 0 \\
\hline Avoiding classroom tasks given by the teacher & 11 & 38 & 47 & 4 \\
\hline Lie to the teacher & 6 & 54 & 38 & 2 \\
\hline Complaining about friends to the teacher & 20 & 10 & 33 & 37 \\
\hline Constantly objecting to the teacher & 9 & 55 & 34 & 2 \\
\hline Arriving late to class & 0 & 26 & 62 & 12 \\
\hline Absence from school without a valid reason & 0 & 64 & 36 & 0 \\
\hline Making unnecessary noise & 2 & 20 & 68 & 10 \\
\hline Talking in class without asking permission & 2 & 20 & 72 & 6 \\
\hline Talking outside the subject of the lesson & 2 & 47 & 43 & 8 \\
\hline Come to class without studying & 6 & 29 & 53 & 12 \\
\hline Not doing the assigned homework & 6 & 52 & 40 & 2 \\
\hline Not bringing course materials to school & 6 & 53 & 37 & 4 \\
\hline Wandering aimlessly around the classroom & 2 & 64 & 34 & 0 \\
\hline Singing or whistling in the lesson & 36 & 51 & 11 & 2 \\
\hline Laughing in class and making their friends laugh & 2 & 29 & 58 & 11 \\
\hline Being indifferent to the lesson and what is being told & 2 & 48 & 44 & 6 \\
\hline Eating and drinking during the lesson & 19 & 50 & 25 & 6 \\
\hline Playing with his/her own or his/her friends' things & 13 & 61 & 20 & 6 \\
\hline Unnecessarily wanting to leave the classroom & 18 & 64 & 14 & 4 \\
\hline Damaging their friends' belongings & 14 & 76 & 10 & 0 \\
\hline Yelling at their friend & 13 & 48 & 39 & 0 \\
\hline Swearing at their friend & 11 & 49 & 29 & 11 \\
\hline Hitting or pushing & 6 & 65 & 19 & 10 \\
\hline Damage to class belongings & 15 & 49 & 36 & 0 \\
\hline Doing a job given by the teacher by lingering & 7 & 49 & 38 & 6 \\
\hline Not paying attention to appearance, clothes, cleanliness & 5 & 52 & 39 & 4 \\
\hline Bringing their belongings to the lesson & 20 & 23 & 32 & 25 \\
\hline
\end{tabular}




\section{IIacrothink}

\subsection{Results of the Second Sub-Problem}

When the data belonging to the second sub-problem examined in order to determine the methods physical education teachers used against to misbehaviors, it has been determined that the method of "pretending to walk up to student" is never used at the rate of $63 \%$, the method of "taking the student out of the classroom" is never used at the rate of $82 \%$, the method of "not allowing the student to go to recess" is never used at the rate of $80 \%$, and the method of "punishing the student physically" is never used at the rate of $89 \%$.

The methods that teachers seldom use include "to tell the student that you are upset or offended by his/her behavior" at the rate of $66 \%$, "notifying the student's family" at the rate of $70 \%$, "ignoring" at the rate of $83 \%$, and "yelling at the student" at the rate of $84 \%$.

The methods that teachers usually use include "reminding the student about the classroom rules" at the rate of $61 \%$, "warning the student with appropriate speech" at the rate of $65 \%$, "trying to understand the reason for the student's behavior" at the rate of $70 \%$, and "attracting the student's attention to the lesson by asking questions about the subject of the lesson" at the rate of $77 \%$.

The methods that teachers always use include "warning the student with appropriate speech" at the rate of $27 \%$, and "rewarding positive behaviors" at the rate of $77 \%$. 
Table 2. Percentages of methods used by physical education teachers

\begin{tabular}{|c|c|c|c|c|}
\hline Misbehaviors $(\mathrm{n}=100)$ & Never $(\%)$ & Seldom $(\%)$ & Usually (\%) & Always (\%) \\
\hline Ignoring & 2 & 83 & 15 & 0 \\
\hline Warning the student with appropriate speech & 0 & 8 & 65 & 27 \\
\hline Yelling at the student & 4 & 84 & 12 & 0 \\
\hline Talking to the student after lesson & 10 & 44 & 37 & 9 \\
\hline Reminding the student about the classroom rules & 0 & 25 & 61 & 14 \\
\hline Pretending to walk up to student & 63 & 34 & 3 & 0 \\
\hline Nonverbal warning of the student & 11 & 54 & 29 & 6 \\
\hline $\begin{array}{l}\text { To tell the student that you are upset or offended by } \\
\text { his/her behavior }\end{array}$ & 28 & 66 & 6 & 0 \\
\hline $\begin{array}{l}\text { Attracting the student's attention to the lesson by asking } \\
\text { questions about the subject of the lesson }\end{array}$ & 2 & 13 & 77 & 8 \\
\hline Making changes in the subject or method of the lesson & 6 & 59 & 33 & 2 \\
\hline Assign more homework to the student & 62 & 31 & 7 & 0 \\
\hline Trying to understand the reason for the student's behavior & 2 & 9 & 70 & 19 \\
\hline Taking the student out of the classroom & 82 & 16 & 2 & 0 \\
\hline Warning the student by touching & 38 & 46 & 16 & 0 \\
\hline Not allowing the student to go to recess & 80 & 11 & 3 & 6 \\
\hline Demonstrating a student with positive behavior & 2 & 17 & 54 & 27 \\
\hline Rewarding positive behaviors & 6 & 6 & 60 & 28 \\
\hline Making the student stand on one leg & 76 & 18 & 6 & 0 \\
\hline Not allowing the student to participate in fun class activities & 52 & 28 & 20 & 0 \\
\hline Punishing the student by giving them an in-class task & 34 & 54 & 10 & 2 \\
\hline Sending the student to the school administrator & 58 & 39 & 3 & 0 \\
\hline Notifying the student's family & 23 & 70 & 5 & 2 \\
\hline Punishing the student physically & 89 & 8 & 0 & 3 \\
\hline
\end{tabular}

\section{Discussion}

According to the findings obtained, it has been revealed that the behavior that the physical education teachers in the research group always encounter is complaining about friends to the teacher, the behavior they usually encounter is talking in class without asking permission, the behavior they seldom encounter is damaging their friends' belongings, the behavior they have never encountered is singing and whistling in class. According to the results of Korkmaz et al. (2007) study, the most common misbehaviors that physical education teachers encounter are talking without asking permission in the class, behaving in a way that will disrupt the flow of the lesson, and speaking in an extremely disturbing way. According to the results of the study conducted by Korkmaz et al. (2007), it was found that the behaviors of sleeping in the lesson, 
standing up and having materials not related to the lesson are the least common behaviors. These results are similar to the results of the research. In addition, Cothran and Kulinna (2007) listed the most common misbehaviors reported by teachers as dodging participation, disrespectful, and complaining. There is partial similarity between these studies.

In the study of Balay and Sağlam (2008), the teachers stated that the behaviors of interrupting the other person, talking/whispering without permission, arriving late to class, standing up without permission/walking around the classroom, and sprawl on the chair were the most observed behaviors, respectively. On the other hand, they reported that the behaviors of using/playing with cell phone, reading newspapers or magazines in the class, sleeping in class, having materials not related to the lesson and leaving class early were the least observed behaviors. As in all the studies mentioned, Kulinna et al. (2006) stated that the most common undesirable behavior is talking.

The results of Kocabey (2008) study, aggressive behaviors towards friends, talking rudely and abusively with friends, distractibility, disturbing other students in their studies by talking constantly, and deliberately speaking to disrupt the lesson are expressed as the most common misbehaviors that teachers encountered. According to the observation findings, the most observed misbehaviors in the classrooms were speaking without permission, standing up and walking around the classroom, interrupting a friend or teacher, and irregular asking for a speech. In regard to the results of Danaoğlu (2009)'s study, the behaviors most frequently encountered by teachers are talking to each other, speaking without permission, and intentionally disrupting the flow of the lesson. These results are similar to the research results. The findings obtained as a result of this research are consistent with the findings of other researches in this field. This revealed that the misbehaviors often encountered are similar. Although common misbehaviors are similar, studies show that misbehaviors in physical education classes can vary according to gender, grade level and ethnicity (Cothran \& Kulinna, 2007). Therefore, these characteristics of students should be taken into account.

According to the findings related to the second sub-problem, it was revealed that the most frequently used method by physical education teachers was to attracting students' attention to the lesson by asking questions about the subject of the lesson, yelling at the student and ignoring them. Another result obtained is, they never used the methods of punishing the student physically, taking the student out of the classroom, and not allowing the student to go to recess. Danaoğlu (2009) also found similar results in her research. According to the research, it was observed that teachers most frequently used verbal warning, researching the cause of the behavior, and ignoring.

In the study conducted by Lewis (2000), teachers suggested that they should use more positive methods in communication and intervention against misbehaviors, being aware of the fact that they use negative methods more. Teachers should listen, empathize and not shout, scold, blame, prejudice, etc. Even if it is a little, they also suggested negative methods such as inflict a disciplinary punishment, punishment, threatening with a grade, threatening to send them to discipline, reporting to the school administration, stricter discipline and embarrassing. 
In the study of Girmen et al. (2006), it was seen that the teachers most frequently used the method of reminding the rules. The findings obtained as a result of this research are consistent with other researches in this field. This revealed that the misbehaviors generally encountered and the methods applied for their solution are similar. However, Kulinna et al. (2006) state that student misbehaviors vary according to teachers' sex, years of teaching experience, and school context. Accordingly, the methods used may differ according to these variables.

Disturbing situations may occur when students have to wait for a long time, the teacher talks a lot, the teacher does not maintain attention on the whole class, or the teacher does not intervene. Teachers' awareness is critical as these situations can lead to devastating situations (Hovdal et al., 2021). Teachers who pay attention to this issue can prevent unwanted behaviors before they occur. It is an undeniable fact that misbehaviors exist and will continue to happen. For this reason, it may be a useful approach to use elements that will reduce student' misbehaviors or support education life such as sports (Chang et al., 2021). Different methods can also be evaluated and tested in this context.

\section{Conclusion}

In this study, it was aimed to determine the student misbehaviors that physical education teachers working in schools in a central district of Ankara encountered and the methods that teachers use against these behaviors. According to the results, it was revealed that the misbehavior that the physical education teachers always encounter was "complaining about friends to the teacher". It has been concluded that they usually encounter behaviors such as "arriving late to class", "making unnecessary noise" and "talking in class without asking permission". The method that physical education teachers always use against misbehaviors is "rewarding positive behaviors". It has been revealed that they usually use the method of "attracting the student's attention to the lesson by asking questions about the subject of the lesson".

\section{References}

Aldrup, K., Klusmann, U., Lüdtke, O., Göllner, R., \& Trautwein, U. (2018). Student misbehavior and teacher well-being: Testing the mediating role of the teacher-student relationship. Learning and Instruction, 58, 126-136. https://doi.org/10.1016/j.learninstruc. 2018.05.006

Balay, R., \& Sağlam, M. (2008). Sınıf İçi Olumsuz Davranışlara İlişkin Öğretmen Görüşleri. Yüzüncü Yıl Üniversitesi, Ĕ̈itim Fakültesi Dergisi, 5(2), 1-24.

Başar, H. (1999). Sınıf Yönetimi. Ankara: MEB Yayınları.

Başar, H. (2010). Sınıf Yönetimi (16th ed.). Ankara: Anı Yayıncılık.

Chang, M., Bang, H., Kim, S., \& Nam, J. (2021). Do sports help students stay away from misbehavior, suspension, or dropout? Studies in Educational Evaluation, 70, 101066. https://doi.org/10.1016/j.stueduc.2021.101066 
Cothran, D. J., \& Kulinna, P. H. (2007). Students' reports of misbehavior in physical education. Research Quarterly for Exercise and Sport, 78(3), 216-224. https://doi.org/ 10.1080/02701367.2007.10599419

Daddis, C., \& Meadows, E. (2021). Middle school students' engagement in and beliefs about student misbehavior: A social domain approach. Journal of Adolescence, 90, 66-78. https://doi.org/10.1016/j.adolescence.2021.06.004

Danaoğlu, G. (2009). Student' misbehaviours and investigating tackling strategies of primary teachers and branch teachers in fifth classes of primary education (Unpublished Master's thesis, Çukurova University, Adana).

Girmen, P., Anılan, H., Şentürk, İ., \& Öztürk, A. (2006). Reaction of primary teacher towards unwanted student behaviors. Manas Üniversitesi Sosyal Bilimler Dergisi, 8(15), 235-244.

Harrison, M. J., \& Blakemore, C. L. (1992). Instructional Strategies for Secondary School Physical Education. Dubuque: Wm. C. Brown Publishers.

Hovdal, D. O. G., Larsen, I. B., Haugen, T., \& Johansen, B. T. (2021). Understanding disruptive situations in physical education: Teaching style and didactic implications. European Physical Education Review, 27(3), 455-472. https://doi.org/10.1177/1356336X 20960498

Hsu, W. T., \& Pan, Y. H. (2018). Moral Disengagement and Student Misbehavior in Physical Education. Journal of Sports Science \& Medicine, 17(3), 437-444.

Kaya, Z. (2002). Sınıf Yönetimi. İstanbul: Pegem Yayıncılık. https://doi.org/10.14527/ 9786052418864

Kocabey, A. (2008). Student' misbehaviours faced by primary teachers in the applicaton of new 2005 primary education program (Unpublished Master's thesis, Çukurova University, Adana).

Kohútová, K., Almašiová, A., \& Petlák, E. (2021). Typology of teachers in terms of perceived students' misbehavior-differences in teachers' self-efficacy. Pedagogika, 142(2), 105-116. https://doi.org/10.15823/p.2021.142.6

Korkmaz, F., Korkmaz, N. H., \& Özkaya, G. (2007). Beden eğitimi öğretmenlerinin öğrenme ortamını bozan davranışlara karşı geliştirdikleri davranış stratejileri. Journal of Uludag University Faculty of Education, 20(1), 67-68.

Kulinna, P. H., Cothran, D. J., \& Regualos, R. (2006). Teachers' reports of student misbehavior in physical education. Research Quarterly for Exercise and Sport, 77(1), 32-40. https://doi.org/10.1080/02701367.2006.10599329

Lemlech, J. K. (1988). Classroom Management. Newyork: Longman Press.

Lewis, R. (2000). Classroom discipline and student responsibility: The students' view. Teaching and Teacher Education, 17(3), 307-319. https://doi.org/10.1016/S0742-051X (00)00059-7 
Sayın, N. (2001). Undesirable behaviors encountered by classroom teachers and their opinions about the reasons of those behaviors and the methods for preventing them (Unpublished Master's thesis, Anadolu University, Eskişehir).

Thilagaratnam, J. S. J., \& Yamat, H. (2021). Teachers' perception of students' misbehavior and assertive discipline in English classroom. International Journal of English Language Studies, 3(3), 07-15. https://doi.org/10.32996/ijels.2021.3.3.2

\section{Copyright Disclaimer}

Copyright for this article is retained by the author(s), with first publication rights granted to the journal.

This is an open-access article distributed under the terms and conditions of the Creative Commons Attribution license (http://creativecommons.org/licenses/by/3.0/). 